\title{
A REAÇÕES DOS AGENTES DO CATOLICISMO POPULAR TRADICIONAL AO PENTECOSTALISMO
}

\author{
Susana Araújo*
}

As proposições lançadas por Oro, neste estudo, me levaram a pensar a relação (e reação) dos agentes do catolicismo popular tradicional aos adeptos das seitas pentecostais.

O estudo de Sanchis (1994), neste sentido, é elucidativo de uma cultura católico-brasileira, entendida em uma dupla perspectiva: como instituição legal e religião civil, representante dos interesses do "povo brasileiro". Ideologia criada no final do século passado e início deste pelos agentes da igreja católica, quando esta, tenta reconquistar seu lugar no espaço público, rompido pela separação da Igreja e do Estado. E enquanto uma religião ligada a tradição, originada na confluência sincrônica e diacrônica de várias identidades articuladas, o que confere sua propensão sincrética (Sanchis, 1994).

Utilizo os dados de minha pesquisa de campo na Ilha da Pintada, Porto Alegre, RS, com os agentes do catolicismo popular tradicional $^{1}$, ou seja, as benzedeiras (católicas) e seus familiares. Ancorada também em alguns contatos com "crentes" da Igreja Assembléia de Deus, denominação esta implantada na Ilha da Pintada desde 1933.

Ao estudar as crenças em bruxas e bruxarias entre os ilhéus e as práticas religiosas a elas relacionadas, percebi que a categoria

* Suzana Araújo é mestranda do PPGAS - UFRGS e prepara dissertação sobre bruxaria.

1 Utilizo o conceito de catolicismo popular tradicional na definição de Steil, como "urn conjunto de crenças e práticas socialmente reconhecidas e partilhadas por urn número significativo de católicos que mantém uma independência relativa da hierarquia eclesiástica e dos quadros intelectuais a elas ligados. De urn ponto de vista subjetivo, podemos entendê-Io como uma maneira religiosa peculiar de urn grupo ou indivíduo viver a sua fé. Num sentido objetivo, trata-se de urn sistema religioso centrado no culto aos santos, compreendido dentro de uma lógica contratual de relações interpessoais, e mantido por urn corpo difuso de agentes religiosos leigos" (Steil, 1997).

Debates do NER, Porto Alegre, ano 1, n. 1, p. 77-79. Novembro de 1997. 
bruxaria é percebida e interpretada de modo diferente entre os católicos tradicionais e os pentecostais do local. No primeiro caso, a bruxaria é considerada uma ação involuntária de algumas mulheres e possuí vítimas preferenciais: recém-nascidos e mulheres grávidas. A bruxaria revela urn sistema de acusações e "fofocas" entre os ilhéus, sobre quem teria embruxado as crianças, como desfazer este embruxamento e quem seria a bruxa. Enquanto que entre os pentecostais, este fenômeno é reinterpretado e englobado junto a diferentes práticas de adivinhação sob a rúbrica de manifestação demoníaca. A categoria bruxaria é deslocada para a idéia de demônio. Uma demarcação que identifica os grupos pentecostais e neopentecostais, bem como o pensamento moderno sobre a bruxaria. O pacto com o demônio, é o que vai marcar e dar especificidade a bruxaria na Europa Moderna (Madeira s/d). Entre os católicos tradicionais da Ilha da Pintada, porém, essa idéia de demônio dificilmente é acionada nas narrativas de bruxas e bruxarias.

Como se sabe, a bruxaria é anterior ao próprio catolicismo, devendo o fenômeno de perseguição e caça às bruxas ser entendido dentro de uma forte cultura eclesiástica da época - séculos XVI, XVII e XVIII - com os movimentos da Reforma Protestante e da Contra Reforma Católica, acompanhada da Inquisição. Como sugere o estudo de Ginzburg (1991), que analisa este período histórico, o fenômeno da bruxaria é o resultado híbrido entre cultura folclórica e cultura erudita, sendo o demônio uma introdução da cultura erudita, para justificar as perseguições e caça às bruxas. Segundo Kochakowicz (1987:256): "Neste campo católicos e protestantes partilhavam os meritos literários, assim como partilhavam o zelo no queimar das bruxas". Visão que é contraditória com os pressupostos da Modernidade mas, ao que tudo indica, funciona como fator de integração e organização social entre grupos com posturas religiosas distintas.

Deste modo, verifiquei em minha pesquisa que, no caso de nove acusações (levantadas durante o trabalho de campo) de bruxas e lobisomens, três acusados "casualmente" são pentecostais. Não seria esta, também, uma forma de reação simbólica ao pentecostalismo (e seus agentes) por parte dos católicos tradicionais da Ilha da Pintada?

Pelo que estou observando até o momento em meu universo de estudo, é como se o catolicismo tradicional praticado na Ilha da

Debates do NER, Porto Alegre, ano 1, n. 1, p. 77-79. Novembro de 1997. 
Pintada pertencesse a uma tradição mais profunda, onde a categoria bruxaria faz parte do universo cognitivo destes agentes do catolicismo popular tradicional e as narrativas sobre bruxas e bruxarias constituíssem urn modo destes ilhéus se pensarem enquanto grupo. Ao passo que, para os fiéis da Assembléia de Deus, esta categoria parece não mais estar presente da mesma forma, havendo sempre urn deslocamento da idéia de bruxaria para a idéia de demônio. Não afirmo com isto que haja uma continuidade temporal (linear) entre bruxas e demônios, mas sim processos históricos de longa duração; não sucessão de modelos temporais e sim superposições, influências mútuas, deslocamentos.

\section{Referências Bibliográficas}

GINZBURG, Carlo. Historia Noturna: Decifrando o Sabá. São Paulo. Companhia das Letras, 1991.

KOCHAKWICZ, Leszek. Diabo. In: Enciclopedia Einaudi, Vol 12 Mythos/Logos - Sagrado/Profano. Imprensa Nacional Casa da Moeda, 1987.

MADEIRA, Angélica. O Pacto da Bruxaria. In: Racional ou Sobrenatural? Um caso de bruxaria. Humanidades, v. $9, \mathrm{n}^{\circ} 1$ (s/d).

ORO, Ari. Neo-pentecostalismo. Cadernos de Antropologia, UFRGS, n. $9,1992$.

Neopentecostais e afro-brasileiros: Quem Vencerá Esta Guerra? Debates do NER, ano I, n. L, 1997.

SANCHIS, Pierre. O Repto Pentecostal à Cultura Católico-brasileira. In: ANTONIAZZI, Alberto et alii. Nem Anjos Nem Demônios: Interpretações Sociológicas do Pentecostalismo. Petrópolis, Rio de Janeiro, Vozes, 1994.

STEIL, Carlos Alberto. CEBs e Catolicismo Popular. In: STEIL, C. A. et alii. As comunidades de base em questão. Sao Paulo, Paulinas, 1997.

Debates do NER, Porto Alegre, ano 1, n. 1, p. 77-79. Novembro de 1997. 